\title{
Melatonin may prevent or reverse polycystic ovary syndrome in rats
}

\author{
(iD)Leonardo Augusto Lombardi ${ }^{1}$ \\ (iD) Leandro Sabará de Mattos ${ }^{1}$ \\ (iD) Ricardo Santos Simões ${ }^{2}$ \\ (iD) Rinaldo Florencio-Silva ${ }^{1}$ \\ (Disela Rodrigues da Silva Sasso ${ }^{1}$ \\ (iD) Adriana Aparecida Ferraz Carbonel ${ }^{1}$ \\ (iD) Manuel Jesus Simões ${ }^{1}$ \\ (iD) Edmund Chada Baracat ${ }^{2}$ \\ (iD) José Maria Soares $/ r^{2}$
}

1 Departamento de Morfologia e Genética, Escola Paulista de Medicina da Universidade Federal de São Paulo, EPM/Unifesp, São Paulo, SP, Brasil 2 Departamento de Obstetrícia e Ginecologia, Faculdade de Medicina da Universidade de São Paulo, FMUSP, São Paulo, SP, Brasil.

http://dx.doi.org/10.1590/1806-9282.65.7.1008

\section{SUMMARY}

OBJECTIVE: To evaluate the ovarian effects of melatonin (Mel) in a rat model of polycystic-ovary-syndrome (PCOS) before and after permanent estrus induction.

METHODS: Thirty-two adult-female rats with regular estrous cycle were equally divided into four groups: 1) GCtrl - at estrous phase. 2) GPCOS - at permanent-estrous phase. 3) GMel1 - treated for 60 days with $\mathrm{Mel}(0.4 \mathrm{mg} / \mathrm{Kg})$ during permanent estrus induction and 4) GMel2 - rats with PCOS and treated for 60 days with Mel. After that, the animals were euthanized, and the ovaries were removed and processed for paraffin embedding. Sections were stained with H.E. for histomorphometry or subjected to immunohistochemistry for Ki-67 and cleaved caspase-3 (Casp-3) detections.

RESULTS: The GPCOS showed lack of corpus luteum and several ovarian cysts, as well as interstitial-like cells. The presence of corpus luteum and a significant increase in primary and antral follicles were observed in Mel-treated groups, which also showed a decrease in the number of ovarian cysts and in the area occupied by interstitial-like cells. These results were more evident in GMel1. The percentage of Ki-67-positive cells was significantly higher in the Mel-treated groups, mainly in the GMel2, as compared to GPCOS. On the other hand, the percentage of Casp-3-positive cells was significantly lower in granulosa cells of GMel1, whereas it was significantly higher in the interstitial-like cells of GMel2, in comparison to GPCOS.

CONCLUSION: Melatonin administration prevents the permanent estrus state in the PCOS rat model. This effect is more efficient when melatonin is administered before permanent estrus induction.

KEYWORDS: Ovary. Melatonin. Polycystic Ovary Syndrome. Estrous cycle. Rats.

\section{INTRODUCTION}

Among several causes of infertility, PCOS stands out due to its frequency, as it affects nearly 5 to $10 \%$ of women during reproductive life ${ }^{1,2}$. Various animal models have been developed to mimic PCOS, among them PCOS induction through continuous illumination exposure is widely used. This induces the animal to an estrous-permanent condition, associated with anovulation, presence of multiple cysts, and an increase in

DATE OF SUBMISSION: 01-Apr-2019

DATE OF ACCEPTANCE: 20-Apr-2019

CORRESPONDING AUTHOR: Manuel Simoes

Rua Botucatu, 740 - Ed. Lemos Torres - São Paulo - SP - Brasil

04021-001 - Tel: 55764848 Voip 1112

E-mail: mjsimoes_43@hotmail.com 
androgens and estrogens serum levels, along with the reduction in melatonin synthesis ${ }^{3}$.

Studies have been suggested that the reduction of melatonin levels would be responsible for the development of ovarian cysts ${ }^{4}$. In a previous study carried out by our group, we observed an increase in the area occupied by interstitial cells, as well as the lack of corpus luteum in ovaries of rats in the estrous-permanent condition, induced by continuous light exposure. It was also suggested that the interstitial cells of the polycystic ovary of rats probably come from ovarian cysts, due to the degeneration of granulosa cells and the differentiation of theca interna cells ${ }^{5}$. An increase in cleaved caspase-3 immunoreactivity in the granulosa cells of ovarian cysts and the lack of Ki-67 immunolabeling in ovarian interstitial cells have also been identified, suggesting that these cells may originate from another cell type ${ }^{6}$.

Animal and human studies indicate that there is a direct action of melatonin on ovarian function, including a systematic alteration in ovarian steroidogenesis, mainly progesterone synthesis. Pinealectomized rats displayed fertility reduction with a decrease in the number of oocytes, in addition to problems during the gestation period and melatonin serum levels reduction. It has been demonstrated that melatonin treatment is safe due to its low toxicity, even when high doses are administered. Moreover, its administration seems to display satisfactory results in the protection and treatment of reproductive dysfunctions ${ }^{7}$. However, the effects of melatonin in the prevention and treatment of PCOS are still poorly understood.

Thus, this study aims to evaluate the ovarian effects of melatonin (Mel) in a rat model of polycystic ovary syndrome before and after permanent estrus induction.

\section{METHODS}

\section{Study design}

This prospective experimental study used thirty-two and three-months-old virgin female rats (Rattus norvegicus albinus) with $\pm 250 \mathrm{~g}$ of body weight, provided by the Center for the Development of Experimental Models (CEDEME) at the São Paulo School of medicine, Federal University of São Paulo (UNIFESP/ EPM). This study was initially approved by the Research Ethics Committee at UNIFESP/EPM (Report $\mathrm{n}^{\mathrm{o}}$ 0179/12), following the guidelines of the Canadian Council on Animal Care ${ }^{8}$.
After a period of seven days of adaptation to the new environment, all animals were subjected to a daily collection of vaginal secretions, for seven consecutive days, in order to evaluate ovarian function. Based on the result of this examination it was possible to observe regular estrous cycles, demonstrating normal ovarian functions. Only rats with regular estrous cycles were included in the study. Then, the rats were randomly divided into four groups: 1) GCtrl - at physiological-estrous phase. 2) GPCOS - at permanent-estrous phase induced by 60 days of continuous illumination (rats with PCOS). 3) GMel1 - PCOS rats daily treated with $\mathrm{Mel}(0.4 \mathrm{mg} / \mathrm{Kg}$ diluted in $500 \mathrm{ml}$ of drinking water) during 60 consecutive days, preemptively, and 4) GMel2 - PCOS rats, which remained exposed to 60 days of continuous illumination and treated with $\mathrm{Mel}^{9}$. It is noteworthy that the animals of the GMel2 group remained under continuous illumination during a total period of 120 days (60 initial days for the induction of the estrous-permanent condition and 60 additional days during the treatment period).

To obtain animals with PCOS, the rats were placed in wooden boxes, kept in a vivarium under continuous artificial lighting using lamps (Philips, Daylight Model, 40W) that provided about 400 Lux in the region occupied by the rats over a period of 60 consecutive days. The GPCOS animals remained in the same standard vivarium conditions, but their lighting period was from 7 am to $7 \mathrm{pm}$. After that, the collection of vaginal secretions for seven consecutive days was carried out again, in order to analyze the phases of the estrous cycle. Then, only the animals of the GCtrl that showed regular estrous cycle, as well as the ones of the GPCOS group that were at estrous-permanent condition were used.

Afterward, the animals were anesthetized with 15 $\mathrm{mg} / \mathrm{kg}$ xylazine (Rompun ${ }^{\circledR}, \mathrm{SP}$, Brasil) associated with $30 \mathrm{mg} / \mathrm{kg}$ ketamine (Ketalar ${ }^{\circ}$, SP, Brasil) intraperitoneally and placed in a supine position. Subsequently, after a longitudinal median incision made at the abdomen, the ovaries were removed and immediately fixed for $24 \mathrm{~h}$ in 10\% formaldehyde (PBS 10mM, pH 7.2). Subsequently, the ovaries were dehydrated in ascending concentrations of ethanol, cleared in xylene, and embedded in paraffin. By using a microtome (Minot, Leica) $5 \mu \mathrm{m}$-sections were obtained from the paraffin blocks, with a distance of $50 \mu \mathrm{m}$ from each section. Sections were collected on histological slides and subsequently stained with hematoxylin and eosin (HE), whereas others were subjected to immunohistochemical methods. 
After removing the ovaries, the animals were euthanized by deepening the plane of anesthesia and disposed of following current standards at the São Paulo School of medicine (UNIFESP/EPM).

\section{Morphological and morphometric analyses}

The evaluation of the slides was carried out at the laboratory of Histology/ UNIFESP/EPM. For the quantification of the parameters evaluated, images were captured by using a high-resolution camera (AxioCam-MCR, Carl Zeiss) adapted to a light microscope (Axiolab, Carl Zeiss) adjusted to a 40X objective lenses and were transmitted to a computer with AxioVision Rel 4.2 software (Carl Zeiss). For the estimation of nuclear volumes of interstitial cells, ten images of each ovary of each rat were obtained, comprising 80 images per group. Posteriorly, the lower and the larger diameter of 10 cells/images were measured and applied to the following formula: $\mathrm{v}=\mathrm{a}^{2} \cdot \mathrm{b} / 1.91$ wherein $\mathrm{a}=$ lower diameter and $b=$ larger diameter, and 1.91 represents a constant $t^{5}$. The determination of the occupied area by interstitial cells was expressed as a percentage, under objective lenses of 10x. Initially, the total ovarian area and the area occupied by interstitial cells in 10 slices of each ovary/animal were measured. Then, the proportion of the area occupied by interstitial cells in relation to the total ovarian area was calculated as a percentage in each section. In this same magnification, the number of ovarian follicles presented in 10 sections of each ovary/animal was counted and classified as primary and antral follicles.

\section{Immunohistochemical analysis}

Immunohistochemical reactions for the detection of Ki-67 and Casp-3 were carried out to analyze cell proliferation and apoptosis, respectively ${ }^{6}$. Sections were collected on silanized slides and subsequently dewaxed in xylene and hydrated in decreasing concentrations of ethanol. The endogenous peroxidase activity was blocked by incubating the sections with
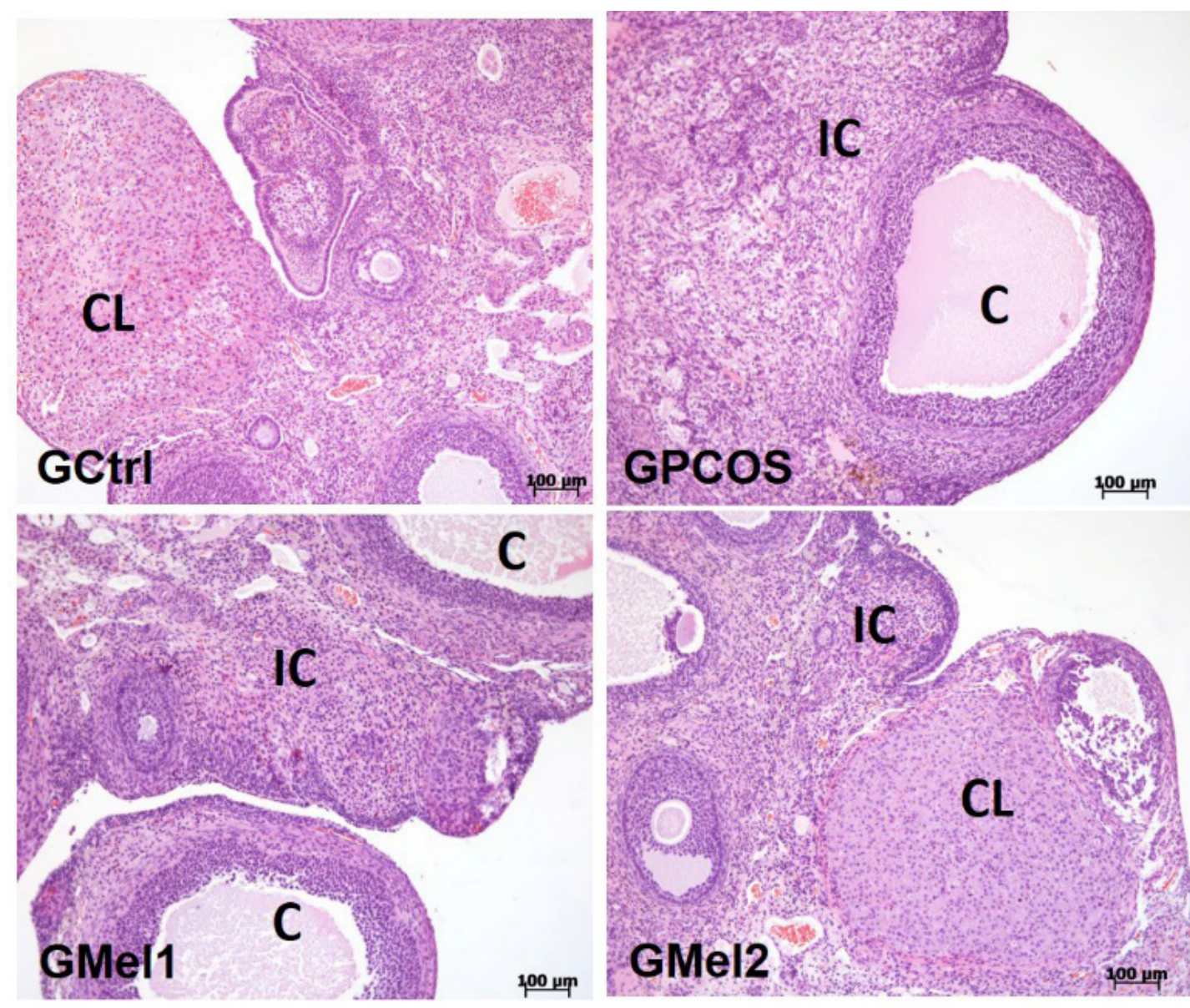

FIGURE 1. Photomicrographs of histological sections of ovarian regions from all groups. It is possible to see a portion of a corpus luteum (CL) of the GCtrl group; and the presence of a cyst in GPCOS (C). In GPCOS, GMel 1, and GMe2, we see the presence of interstitial cells (IC) and corpora lutea in the GMel2. H.E staining. 
$3 \%$ hydrogen peroxide for 5 minutes. The sections were incubated in a sodium citrate buffer ( $\mathrm{pH}$ 6.0), $10 \mathrm{mM}$ at $95^{\circ} \mathrm{C}$ for 20 minutes and non-specific binding sites were blocked with 2\% PBS-BSA for 1 hour. Sections were then incubated overnight in the following primary antibodies: anti-Ki-67 (MIB-5, Dako, Denmark, United Kingdom) and anti-cleaved caspase-3 (Asp175-antibody \#9661, Cell Signaling Technology, Beverly, USA), diluted at 1:200 and 1:100, respectively. Afterward, the sections were incubated in a biotinylated goat anti-mouse/rabbit (Ig, Duet kit Dako) secondary antibody; reactions were revealed with the streptavidin-peroxidase system (Dako Cytomation, USA) using 3,3'-diamino-benzidine (DAB) as a chromogen and counter-stained with hematoxylin. As a negative control, primary antibodies were replaced by non-specific immunoglobulin (DAKO Cytomation, USA). The frequency of Ki-67 and cleaved caspase-3 immunolabeled cells were expressed as a percentage (\%), and a last 500 cells/animal were counted.

\section{Statistical analysis}

Quantitative data were expressed as mean \pm standard deviation and evaluated by ANOVA test, followed by Tukey test (using the "GraphPad 5 Prism" software. The rejection level for the null hypothesis was set at $1 \%(p<0.01)$, and significant values were marked with an asterisk.

\section{RESULTS}

Morphological and morphometric analyses

The morphological results showed lack of corpus luteum and the presence of multiple ovarian cysts in the GPCOS group. Numerous groups of cells containing large and bulky nuclei and well-evident nucleoli were also observed in the GPCOS group. These cells were organized as spherical and cord-like structures with epithelioid aspect, which are typical characteristics of interstitial cells (Fig.1). On the other hand, the Mel-treated groups showed the presence of corpus luteum, as well as an increase in the number of primary and antral follicles, mainly in the Mel1 group (Fig.1 and Table 1). A significant reduction in the number of cysts and in the area occupied by interstitial cells, as well as a decrease in nuclear volume of these cells, were noticed in the Mel-treated groups, mainly in the Mel1 group (Table 1).

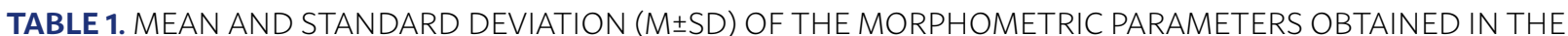
OVARIES OF THE NORMAL ESTROUS CYCLE (GCTRL), ESTROUS-PERMANENT RATS (GPCOS), MEL-TREATED RATS AS PREVENTION (GMEL1) OR AFTER THE INDUCTION OF PERMANENT ESTRUS (GMEL2).

\begin{tabular}{|c|c|c|c|c|}
\hline Parameters & GCtrl & GPCOS & GMel1 & GMel2 \\
\hline $\mathrm{N}^{0}$ Cysts/Ovary & $0^{c}$ & $5.50 \pm 0.36^{\mathbf{a}}$ & $4.15 \pm 0.20^{\mathbf{b}}$ & $4.20 \pm 0.16^{b}$ \\
\hline$N^{0}$ Corpus luteum/Ovary & $4.61 \pm 0.80^{a}$ & $\mathrm{O}^{c}$ & $4.24 \pm 0.70^{a}$ & $3.50 \pm 0.16^{\mathbf{b}}$ \\
\hline $\mathrm{N}^{0}$ Primary follicles $/ 0.04 \mathrm{~mm}^{2}$ & $32.15 \pm 0.15^{a}$ & $20.88 \pm 0.89^{c}$ & $26.40 \pm 0.86^{\mathbf{b}}$ & $25.00 \pm 0.91^{b}$ \\
\hline $\mathrm{N}^{0}$ Antral follicles $/ 0.59 \mathrm{~mm}^{2}$ & $4.45 \pm 0.65^{a}$ & $1.02 \pm 0.03^{c}$ & $4.30 \pm 0.33 a$ & $2.85 \pm 0.06^{\mathbf{b}}$ \\
\hline$\%$ Area of Interstitial Cells & $19.33 \pm 1.07^{d}$ & $52.11 \pm 1.03^{a}$ & $26.60 \pm 2.04^{c}$ & $34.28 \pm 1.20^{\mathbf{b}}$ \\
\hline Nuclear volume of Interstitial Cells $/ \mu m^{3}$ & $7.40 \pm 0.83^{c}$ & $15.40 \pm 1.37^{\mathrm{a}}$ & $8.63 \pm 0.90^{c}$ & $10.23 \pm 0.77^{\mathbf{b}}$ \\
\hline
\end{tabular}

Note: $a>b>c>d$. ${ }^{*} p \leq 0.05$

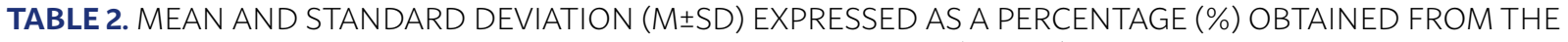
IMMUNOHISTOCHEMICAL ANALYSIS OF NORMAL ESTROUS CYCLE (GCTRL), ESTROUS-PERMANENT RATS (GPCOS), MEL-TREATED RATS AS PREVENTION (GMEL1), OR AFTER THE INDUCTION OF PERMANENT ESTRUS (GMEL2).

\begin{tabular}{|c|c|c|c|c|}
\hline Parameters & GCtrl & GPCOS & GMel1 & GMel2 \\
\hline$\%$ Apoptosis of theca cells & $0.01 \pm 0.02$ & $0.02 \pm 0.01$ & $0.01 \pm 0.01$ & $0.01 \pm 0.01$ \\
\hline$\%$ Apoptosis of granulosa cells & $1.50 \pm 0.02 c$ & $89.05 \pm 7.80^{\mathbf{a}}$ & $32.50 \pm 3.80^{\mathbf{b}}$ & $86.09 \pm 1.80^{a}$ \\
\hline$\%$ Apoptosis of interstitial cells & $0.15 \pm 0.62^{c}$ & $2.20 \pm 0.50^{c}$ & $4.20 \pm 0.40^{\mathbf{b}}$ & $34.04 \pm 2.80^{\mathbf{a}}$ \\
\hline$\%$ Proliferation of theca cells & $2.01 \pm 0.12$ & $2.05 \pm 0.12$ & $2.03 \pm 0.10$ & $2.02 \pm 0.13$ \\
\hline$\%$ Proliferation of granulosa cells & $95.05 \pm 0.20^{a}$ & $5.07 \pm 0.18^{c}$ & $78.07 \pm 0.22^{\mathbf{b}}$ & $92.80 \pm 0.20^{a}$ \\
\hline$\%$ Proliferation of interstitial cells & 0 & 0 & 0 & 0 \\
\hline
\end{tabular}




\section{Immunohistochemical analysis}

The percentage of Ki-67-positive cells (cell proliferation marker) was significantly higher in granulosa cells of the Mel-treated groups when compared to GPCOS group, mainly in the GMel2. Cell proliferation was not observed in interstitial cells of all groups. A weak and not significant Ki-67 immunostaining in the theca cells was also observed in all groups. Conversely, the percentage of Casp-3-positive cells (apoptosis marker) was significantly lower in the granulosa cells of GMel1 (32.50 \pm 3.8$)$, in comparison with the PCOS group, whereas it was significantly higher in the interstitial cells of GMel2 $(34.04 \pm 2.80)$ when compared to the PCOS group. In addition, a weak and not significant Casp-3 immunoreactivity in the theca cells was noticed in all groups (Table 2).

\section{DISCUSSION}

One of the critical hormonal factors in the regulation of follicular development is melatonin. Several authors have demonstrated the presence of their receptors (MT1 and MT2) in the ovarian follicle and support the hypothesis of their role in ovarian physiology ${ }^{9,10}$.

Melatonin may also stimulate follicular development by promoting increased production of insulin-like growth factor I (IGF-I), a major mitogenic growth factor in granulosa cells ${ }^{11}$. Studies have also demonstrated the effect of melatonin (0.1 mM) on IGF-I receptor expression ${ }^{12}$. Our results showed that rats treated with melatonin presented a greater amount of primary and antral follicles, especially when administered before induction to permanent estrus.

Studies have detected the presence of melatonin in follicular fluid from human preovulatory follicles at concentrations higher than serum levels. High levels of melatonin in follicular fluid seem to play an essential role in the growth and proper maturation of ovarian follicles; in contrast, low concentrations may cause anovulation associated with poor oocyte quality in women with $\operatorname{PCOS}^{13}$. However, Shi et al. ${ }^{14}$ reported that small swine follicles $(<3 \mathrm{~mm})$ contained significantly higher concentrations of melatonin than medium $(3-8 \mathrm{~mm})$ and large $(<8 \mathrm{~mm})$ follicles, which may be related to species-specific reproductive characteristics.

Melatonin has an important antioxidant, antiapoptotic, and anti-inflammatory role ${ }^{15}$. These effects act as a potential factor to protect the oocyte and its surrounding cells against damage caused by oxidative stress, thus inhibiting follicular atresia ${ }^{16}$. According to Sun et al. ${ }^{17}$ oxidative stress can cause damage to granulosa cells, increasing the rate of apoptosis of these cells, as well as causing damage to the DNA of oocytes. Our results showed an increase in the number of antral and primary follicles in the melatonin-treated animals when compared to the control group. Moreover, a higher number of ovarian follicles was noticed in the ovaries of animals that received melatonin before induction of permanent estrus state (GMel1). Such findings reinforce the protective effects of melatonin in granulosa cells and ovarian follicles.

High concentrations of melatonin in the preovulatory follicle may be involved with progesterone production, resulting in ovulation and luteinization ${ }^{18}$. In our study, we observed an increase in the number of corpora lutea in melatonin-treated animals, which was more evident in the animals that received melatonin before permanent estrus induction. Zhang et al. ${ }^{16}$ demonstrated in humans the action of melatonin on the production of progesterone in granule-lutein cells. This seems to be mediated in part by the increased melatonin-elicited luteinizing hormone $(\mathrm{LH})$ receptor expression ${ }^{19}$. Woo et al. ${ }^{19}$ demonstrated the action of melatonin on the modulation of follicular response to LH by increasing the expression of mRNA of LH receptors in granulosa cells in humans. The antral follicles recruited for growth are characterized by the increased expression of mRNA for steroidogenic enzymes, receptors for gonadotrophins, and local regulatory factors.

Studies have demonstrated the action of melatonin on the prevention of apoptosis (cell death mechanism) by inducing $\mathrm{Bcl} 2$ expression and reducing the activity of the cleaved caspase- $3^{19,20}$. Such data corroborate our immunohistochemical findings, which showed a significant decrease in cleaved caspase-3 immunoexpression in granulosa cells in animals receiving melatonin before induction to permanent estrus (GMel1). In their study, Sun et al. ${ }^{17}$ also observed relatively low positivity of internal theca cells to the TUNEL method (apoptosis/necrosis) in ovarian cysts of sows. Foghi et al. ${ }^{21}$ also describe the role of Bcl-2 in the apoptosis of theca cells and interstitial cells in rat atretic follicles. Nevertheless, to our knowledge, there are no papers in the literature that clearly describe the apoptosis process of these cells in rats with polycystic ovaries.

A lower Cyp17a1 immunoexpression in theca interna cells has been observed in rats treated with 
melatonin, as compared to the control group. However, in granulosa cells and interstitial cells, the authors did not observe statistically significant differences between melatonin-treated and control groups. In the same study, the authors did not observe differences in the immunoexpression for Cyp19a1 in inner theca cells, granulosa cells, and interstitial cells ${ }^{22}$. These data also corroborate with our morphometric results, where a significant reduction in nuclear volume and area occupied by interstitial cells was observed in the melatonin-treated and control groups, suggesting that melatonin administration induced a decrease in androgen production by interstitial cells, especially in animals that received melatonin as prevention (GMel1).

Studies have suggested a stimulatory effect of melatonin on estrogen production in pig and human granulosa cells ${ }^{16}$. In addition, melatonin has been shown to reduce the expression of PCNA in hormone-dependent tumors of mice, indicating that melatonin has an antiproliferative effect. Such effect does not appear to occur in granulosa cells of rats in permanent estrus or under the stimulus for the induction of permanent estrous state since our results showed a significant increase in Ki-67 expression in granulosa cells.

According to our results, melatonin appears to reestablish the normal process of granulosa cell proliferation in the rat model of PCOS (permanent estrus). Melatonin treatment is safe, accessible, and has low toxicity. Our data indicate that melatonin exerts positive effects on the protection and treatment of reproductive dysfunctions in PCOS.

\section{CONCLUSIONS}

Melatonin administration prevented the permanent estrus state in the PCOS rat model. This effect is more efficient when melatonin is administered before permanent estrus induction.

\section{RESUMO}

OBJETIVO: Avaliar os efeitos ovarianos da melatonina (Mel) em ratas com síndrome dos ovários policísticos (SOP) antes e após a indução do estro-permanente.

MÉTODOS: Trinta e duas ratas com ciclos estrais regulares foram igualmente divididas em quatro grupos: 1) GCtrl - fase de estro. 2) GSOP - fase de estro-permanente. 3) GMel7 - tratadas por 60 dias com Mel (0,4 mg/kg) durante a indução do estro-permanente e 4) GMel2 - ratas com SOP e tratadas com Mel. Após eutanásia dos animais, os ovários foram processados para inclusão em parafina. Cortes foram corados com H. E ou submetidos à imuno-histoquímica para detecção de Ki-67 e caspase-3 clivada (Casp-3).

RESULTADOS: O GSOP mostrou ausência de corpos lúteos e vários cistos ovarianos, além de inúmeras células intersticiais. A presença de corpos lúteos e o aumento significativo dos folículos primários e antrais foram observados nos grupos tratados com Mel, os quais também mostraram diminuição no número de cistos ovarianos e na área ocupada pelas células intersticiais. Esses resultados foram mais evidentes no GMel1 do que no GMel2. A porcentagem de células Ki-67 positivas foi significativamente maior no GMel1 e no GMel2, sendo mais evidente no GMel2, em comparação ao GSOP. Por outro lado, a porcentagem de células positivas à Casp-3 foi menor nas células da granulosa do GMel1 e maior nas células intersticiais do GMel2, em comparação ao GSOP.

CONCLUSÃO: A administração de melatonina previne o estado de estro-permanente em ratas com SOP. Esse efeito é mais eficiente quando a melatonina é administrada após indução do estado de estro-permanente.

PALAVRAS-CHAVE: Ovário. Melatonina. Síndrome do ovário policístico. Ciclo estral. Ratos.

\section{REFERENCES}

1. Goodarzi MO, Dumesic DA, Chazenbalk G, Azziz R. Polycystic ovary syndrome: etiology, pathogenesis and diagnosis. Nat Rev Endocrinol. 2011;7(4):219-31.

2. Batista JG, Soares JM Jr, Maganhin CC, Simões RS, Tomaz G, Baracat EC. Assessing the benefits of rosiglitazone in women with polycystic ovary syndrome through its effects on insulin-like growth factor 1, insulin-like growth factor-binding protein-3 and insulin resistance: a pilot study. Clinics (Sao Paulo). 2012;67(3):283-7.

3. Sara L, Antal P, Masszi G, Buday A, Horvath EM, Hamar P, et al. Arteriolar insulin resistance in a rat model of polycystic ovary syndrome. Fertil Steril. 2012;97(2):462-8.

4. Dardes RC, Baracat EC, Simões MJ. Modulation of estrous cycle and LH, FSH and melatonin levels by pinealectomy and sham-pinealectomy in female rats. Prog Neuropsychopharmacol Biol Psychiatry. 2000;24(3):441-53.

5. Lombardi LA, Simões RS, Maganhin CC, Silva CF, Maciel GA, Baracat EC, et al. Morphology of the interstitial cells of rat polycystic ovaries: an experimental study. Rev Bras Ginecol Obstet. 2012;34(7):323-8.

6. Lombardi LA, Simões RS, Maganhin CC, Baracat MC, Silva-Sasso GR, Florencio-Silva R, et al. Immunohistochemical evaluation of proliferation, apoptosis and steroidogenic enzymes in the ovary of rats with polycystic ovary. Rev Assoc Med Bras (1992). 2014;60(4):349-56.

7. Reiter RJ, Tan DX, Manchester LC, Paredes SD, Mayo JC, Sainz RM. Melatonin and reproduction revisited. Biol Reprod. 2009;81(3):445-56.

8. Olfert ED, Cross BN, McWilliam AA. Canadian Council on Animal Care/ Guide to the Care and Use of Experimental Animals. 2nd ed. Ottawa: Bradda Printing Services; 1993.

9. Maganhin CC, Fuchs LF, Simões RS, Oliveira-Filho RM, lesus Simões M, Baracat EC, et al. Effects of melatonin on ovarian follicles. Eur J Obstet Gynecol Reprod Biol. 2013;166(2):178-84.

10. Soares JM Jr, Simões MJ, Oshima CT, Mora OA, Lima GR, Baracat EC. 
Pinealectomy changes rat ovarian interstitial cell morphology and decreases progesterone receptor expression. Gynecol Endocrinol. 2003;17(2):115-23.

11. Regan KS, Cline JM, Creasy D, Davis B, Foley GL, Lanning L, et al; STP Ovary Evaluation Working Group. STP position paper: ovarian follicular counting in the assessment of rodent reproductive toxicity. Toxicol Pathol. 2005;33(3):409-12.

12. Picinato MC, Hirata AE, Cipolla-Neto J, Curi R, Carvalho CR, Anhê GF, et al. Activation of insulin and IGF-1 signaling pathways by melatonin through MT1 receptor in isolated rat pancreatic islets. J Pineal Res. 2008;44(1):88-94

13. Tamura H, Nakamura Y, Korkmaz A, Manchester LC, Tan DX, Sugino N, et al. Melatonin and the ovary: physiological and pathophysiological implications. Fertil Steril. 2009;92(1):328-43.

14. Shi JM, Tian XZ, Zhou GB, Wang L, Gao C, Zhu SE, et al. Melatonin exists in porcine follicular fluid and improves in vitro maturation and parthenogenetic development of porcine oocytes. J Pineal Res. 2009;47(4):318-23.

15. Tian XZ, Wen Q, Shi JM, Liang-Wang, Zeng SM, Tian JH, et al. Effects of melatonin on in vitro development of mouse two-cell embryos cultured in HTF medium. Endocr Res. 2010;35(1):17-23.

16. Zhang W, Wang Z, Zhang L, Zhang Z, Chen J, Chen W, et al. Melatonin stimulates the secretion of progesterone along with the expression of cholesterol side-chain cleavage enzyme (P450scc) and steroidogenic acute regulatory protein (StAR) in corpus luteum of pregnant sows. Theriogenology. 2018;108:297-305.

17. Sun CL, Qiao J, Hu ZX, Zhang T, Chen YY. Expression of novel apoptosisrelated protein PDCD5 in granulosa cells of polycystic ovary syndrome. Beijing Da Xue Xue Bao Yi Xue Ban. 2005;37(5):476-9.

18. Nakamura $Y$, Tamura $H$, Takayama $H$, Kato H. Increased endogenous level of melatonin in preovulatory human follicles does not directly influence progesterone production. Fertil Steril. 2003;80(4):1012-6.

19. Woo MM, Tai C), Kang SK, Nathwani PS, Pang SF, Leung PC. Direct action of melatonin in human granulosa-luteal cells. J Clin Endocrinol Metab. 2001;86(10):4789-97.

20. Guha M, Maity P, Choubey V, Mitra K, Reiter R], Bandyopadhyay U. Melatonin inhibits free radical-mediated mitochondrial-dependent hepatocyte apoptosis and liver damage induced during malarial infection. | Pineal Res. 2007;43(4):372-81.

21. Foghi A, Teerds KJ, van der Donk H, Moore NC, Dorrington |. Induction of apoptosis in thecal/interstitial cells: action of transforming growth factor (TGF) alpha plus TGF beta on bcl-2 and interleukin-1 beta-converting enzyme. J Endocrinol. 1998;157(3):489-94.

22. Lima GN, Maganhin CC, Simões RS, Baracat MC, Sasso GR, Fuchs LF, et al. Steroidogenesis-related gene expression in the rat ovary exposed to melatonin supplementation. Clinics (Sao Paulo). 2015;70(2):144-51. 